\title{
Impact of Zinc and/or Herbal Mixture on Ruminal Fermentation, Microbiota, and Histopathology in Lambs
}

\section{OPEN ACCESS}

Edited by:

Vincenzo Tufarelli,

University of Bari Aldo Moro, Italy

Reviewed by:

Aristide Maggiolino,

University of Bari Aldo Moro, Italy

Vidica Stanacev,

University of Novi Sad, Serbia

*Correspondence:

Zora Váradyová

varadyz@saske.sk

Specialty section: This article was submitted to Animal Nutrition and Metabolism,

a section of the journal

Frontiers in Veterinary Science

Received: 18 November 2020 Accepted: 08 January 2021

Published: 28 January 2021

Citation:

Petrič D, Mravčáková D, Kucková K, Kišidayová S, Cieslak $A$,

Szumacher-Strabel $M$, Huang $H$, Kolodziejski P, Lukomska A,

Slusarczyk S, Čobanová K and Váradyová Z (2021) Impact of Zinc and/or Herbal Mixture on Ruminal

Fermentation, Microbiota, and

Histopathology in Lambs.

Front. Vet. Sci. 8:630971.

doi: 10.3389/fvets.2021.630971
Daniel Petrič ${ }^{1}$, Dominika Mravčáková ${ }^{1}$, Katarína Kucková ${ }^{1}$, Svetlana Kišidayová ${ }^{1}$, Adam Cieslak ${ }^{2}$, Malgorzata Szumacher-Strabel ${ }^{2}$, Haihao Huang ${ }^{2}$, Pawel Kolodziejski ${ }^{3}$, Anna Lukomska ${ }^{4}$, Sylwester Slusarczyk ${ }^{5}$, Klaudia Čobanová ${ }^{1}$ and Zora Váradyová ${ }^{1 *}$

${ }^{1}$ Institute of Animal Physiology, Centre of Biosciences of the Slovak Academy of Sciences, Košice, Slovakia, ${ }^{2}$ Department of Animal Nutrition, Poznan University of Life Sciences, Poznan, Poland, ${ }^{3}$ Department of Animal Physiology, Biochemistry and Biostructure, Poznan University of Life Sciences, Poznan, Poland, ${ }^{4}$ Department of Preclinical Sciences and Infectious Diseases, Poznan University of Life Sciences, Poznan, Poland, ${ }^{5}$ Department of Pharmaceutical Biology and Botany, Wroclaw Medical University, Wroclaw, Poland

We investigated the effect of diets containing organic zinc and a mixture of medicinal herbs on ruminal microbial fermentation and histopathology in lambs. Twenty-eight lambs were divided into four groups: unsupplemented animals (Control), animals supplemented with organic zinc (Zn, $70 \mathrm{mg} \mathrm{Zn/kg} \mathrm{diet),} \mathrm{animals} \mathrm{supplemented} \mathrm{with} \mathrm{a} \mathrm{mixture} \mathrm{of} \mathrm{dry}$ medicinal herbs (Herbs, $100 \mathrm{~g}$ dry matter (DM)/d) and animals supplemented with both zinc and herbs ( $\mathrm{n}+$ Herbs). Each lamb was fed a basal diet composed of meadow hay $(700 \mathrm{~g} \mathrm{DM} / \mathrm{d})$ and barley (300 g DM/d). The herbs Fumaria officinalis L. (FO), Malva sylvestris L. (MS), Artemisia absinthium L. (AA) and Matricaria chamomilla L. (MC) were mixed in equal proportions. The lambs were slaughtered after $70 \mathrm{~d}$. The ruminal contents were used to determine the parameters of fermentation in vitro and in vivo and to quantify the microbes by molecular and microscopic methods. Samples of fresh ruminal tissue were used for histopathological evaluation. Quantitative analyses of the bioactive compounds in FO, MS, AA, and MC identified 3.961, 0.654, 6.482, and $12.084 \mathrm{~g} / \mathrm{kg} \mathrm{DM}$ phenolic acids and $12.211,6.479,0.349$, and $2.442 \mathrm{~g} / \mathrm{kg}$ DM flavonoids, respectively. The alkaloid content in FO was $6.015 \mathrm{~g} / \mathrm{kg}$ DM. The diets affected the levels of total gas, methane and $n$-butyrate in vitro $(P<0.046,<0.001$, and $<0.001$, respectively). Relative quantification by real-time PCR indicated a lower total ruminal bacterial population in the lambs in the $\mathrm{Zn}$ and $\mathrm{Zn}+$ Herbs groups than the Control group $(P<0.05)$. The relative abundances of Ruminococcus albus, $R$. flavefaciens, Streptococcus bovis, and Butyrivibrio proteoclasticus shifted in the Zn group. Morphological observation found a focally mixed infiltration of inflammatory cells in the lamina propria of the rumen in the $\mathrm{Zn}+$ Herbs group. The effect of the organic zinc and the herbal mixture on the parameters of ruminal fermentation in vitro was not confirmed in vivo, perhaps because the ruminal microbiota of the lambs adapted to the zinc-supplemented diets. Long-term supplementation of a diet combining zinc and medicinal herbs, however, may negatively affect the health of the ruminal epithelium of lambs.

Keywords: bacteria, ciliated protozoa, hematological profiles, histology, phytochemicals, sheep 


\section{INTRODUCTION}

The ruminal microbial fermentation of dietary substrates plays a main role in the ability of ruminants to use fibrous dietary substrates but is also associated with emissions of methane and the excessive excretion of nitrogen in manure. Modern animal production systems require the maintenance of optimal animal health and the safe and efficient production of high-quality animal products. Understanding the ruminal microbiome in all aspects of bacterial, archaeal or eukaryotic populations and in all factors for manipulating the microbiome to maximize productivity while decreasing negative environmental impacts is therefore necessary $(1,2)$.

Our previous results indicated that replacing $10 \%$ of meadow hay with different mixtures of dry medicinal plants could influence the patterns of fermentation $(3,4)$. Recent findings with plant nutraceuticals highlight the dependence of the effect of dry medicinal plants on the variety and synergy of plant polyphenols and the combination of bioactive compounds, which together affect and contribute to a specific pharmacological efficacy $(5,6)$. Zinc plays catalytic, structural and regulatory roles for enzymes, proteins and transcription factors and is thus a key trace element for improving immunological functions $(7,8)$. The bioavailability of zinc in the diets of ruminants also depends on the chemical form, content and interaction of zinc with dietary constituents $(9,10)$. The most recent requirements and recommendations for dietary zinc in ruminants vary between 40 and $130 \mathrm{mg} / \mathrm{kg}$ DM of the complete diet (11). The organic forms of trace elements bound by organic ligands should be more resistant to interactions in the ruminant digestive tract and can be more bioavailable than inorganic sources (12). The rumen of ruminants allows the selective uptake of nutrients generated by intraruminal microbial fermentation because the rumen is covered by a stratified epithelium that consists of leaflike papillae, which greatly increase the area and size of the absorptive surface (13). Epithelial surfaces are complex chemical and biological barriers that prevent the invasion of microbes or other potentially harmful pathogens, but they also harbor many beneficial microorganisms (14).

Our recent in vitro study reported that a mixture of fumitory, mallow, wormwood and chamomile possessed a strong ruminal antioxidant capacity with the potential for inducing desirable changes in the gastrointestinal ecosystem during ruminant fermentation (15). Ruminal volatile fatty acids (VFAs) arise mostly from the fermentation of dietary carbohydrates and are absorbed through the ruminal epithelium; we therefore hypothesized that this herbal mixture, together with organic zinc, would affect not only ruminal fermentation and the microbial population but also ruminal histopathology. Our knowledge is also based on our previous findings indicating that a combination of zinc and a special medicinal herbal mixture can positively influence the health of lambs infected with gastrointestinal nematodes (16). We investigated the effects of dietary supplements containing organic zinc and a mixture of medicinal herbs (Fumaria officinalis L., Malva sylvestris L., Artemisia absinthium L., and Matricaria chamomilla L.) on ruminal fermentation, the microbial population and the histopathology of the lambs.

\section{MATERIALS AND METHODS}

\section{Lambs, Diets, and Experimental Design}

The experimental design followed the standards of the European Union for the protection of animals under European Community guidelines (EU Directive 2010/63/EU). The Ethical Committee of the Institute of Animal Physiology of the Centre of Biosciences of the Slovak Academy of Sciences approved the experimental protocol (resolution no. Ro-4065/18-221/3). Twenty-eight castrated male Improved Valachian lambs $\sim 5$ months old with body weights of $22.6 \pm 2.94 \mathrm{~kg}$ were housed individually in pens for $30 \mathrm{~d}$ for acclimatization to feeding with free access to water. The animals were divided into four groups $(n=7)$ based on their live weights. The experimental treatments were as follows: (a) a basal diet (Control) composed of $700 \mathrm{~g}$ $\mathrm{DM} / \mathrm{d}$ meadow hay and $350 \mathrm{~g} \mathrm{DM} / \mathrm{d}$ ground barley; (b) a basal diet enriched with a zinc chelate of amino acids hydrate ( $\mathrm{Zn}$, $70 \mathrm{mg} \mathrm{Zn} / \mathrm{kg}$ of diet/d); (c) a basal diet enriched with a mixture of herbs (Herbs, $100 \mathrm{~g} \mathrm{DM} / \mathrm{d}$ ); and (d) a basal diet enriched with a combination of zinc and the mixture of herbs ( $\mathrm{Zn}+$ Herbs). Aliquots of zinc Availa-Zn 100 EU (Zinpro Corporation, Eden Prairie, USA) were directly mixed with the ground barley. The mixture of herbs (AGROKARPATY, Plavnica, Slovak Republic) contained 33\% each of F. officinalis (FO), M. sylvestris (MS), and M. chamomilla (MC) and $1 \%$ A. absinthium (AA). All experimental groups received diets for $70 \mathrm{~d}$. The lambs were fed twice daily at the same time each day. Before the feeding on the next day, the feed refused by each lamb was sampled and weighed. All samples of refused feed were composited at the end of the study for each lamb and stored at $-20^{\circ} \mathrm{C}$ for later analysis to evaluate nutrient intake. The lambs were weighed at the beginning of the study and on day 35 (D35) and D70. Samples of blood were collected on D0, D35, and D70 from the jugular vein of each lamb using a 21-gauge needle and syringe and deposited into microtubes containing $1.6 \mathrm{mg} / \mathrm{mL}$ EDTAK3 (Sarstedt AG \& Co, Nümbrecht, Germany). Hematological parameters were immediately determined using an Abbott CELLDYN 3700 automated hematological analyzer (Global Medical Instrumentation, Inc., Ramsey, USA).

All animals were killed according to European Commission rules (Council Regulation 1099/2009) for slaughtering procedures (17) at the end of the experiment on three consecutive days (at the abattoir of the Centre of Biosciences of SAS, Institute of Animal Physiology, Košice, Slovakia, No. SK U 06018). The carcasses were sent to the Department of Pathological Anatomy and Pathological Physiology, University of Veterinary Medicine and Pharmacy in Košice, Slovak Republic. Ruminal contents were collected, and samples of fresh ruminal tissues were fixed in $10 \%$ neutral buffered formalin.

\section{In vitro Experiment}

The experiment was carried out using the in vitro gas production technique (IVGPT) on batch-culture incubations of buffered ruminal fluid (RF) incubated at $39^{\circ} \mathrm{C}$ for $24 \mathrm{~h}$ under anaerobic conditions (18). The ruminal contents were collected separately from each lamb of each treatment immediately after the slaughter in the abattoir, packed in prewarmed flasks and transported 
TABLE 1 | Chemical compositions ( $\mathrm{g} / \mathrm{kg}$ DM) of the dietary ingredients.

\begin{tabular}{|c|c|c|c|c|c|}
\hline Item & $\begin{array}{c}\text { Meadow } \\
\text { hay }\end{array}$ & Barley & Herbs $^{a}$ & $\begin{array}{c}\text { Availa-Zn100 } \\
\text { EU }^{\mathrm{b}}\end{array}$ & $\begin{array}{c}\text { Barley + } \\
\text { Availa-Zn100 }\end{array}$ \\
\hline Dry matter (DM, g/kg) & 894 & 875 & 874 & 976 & 869 \\
\hline Neutral-detergent fiber & 535 & 277 & 390 & 286 & 516 \\
\hline Acid-detergent fiber & 345 & 108 & 217 & 237 & 138 \\
\hline Nitrogen & 23 & 22 & 33 & 34 & 26 \\
\hline Crude protein & 144 & 137 & 206 & 212 & 163 \\
\hline Ash & 77 & 25 & 127 & 361 & 27 \\
\hline
\end{tabular}

${ }^{a}$ Dry medicinal herbs (AGROKARPATY, Plavnica, Slovak Republic); ${ }^{b}$ Availa-Zn 100 EU (Zimpro Corporation, Eden Prairie, USA); ${ }^{c}$ Zn diet, a mixture of zinc (Availa-Zn 100 EU) and ground barley.

to the laboratory as was previously described (3). The ruminal contents were forced through four layers of cheesecloth and pooled in equal volumes based on the dietary treatments of the donor animals. The pooled RF was purged with $\mathrm{CO}_{2}$, mixed with McDougall's buffer (19) in a 1:1 ratio and dispensed in volumes of $35 \mathrm{~mL}$ into fermentation bottles $(120 \mathrm{~mL})$ containing $250 \mathrm{mg}$ (DM basis) of a substrate. Meadow hay ( $\mathrm{MH})$ and barley grain (BG) were used as the basic components of the diet (700:300, w/w) with the use of additive zinc (0.025 g/bottle), herbs $(0.025 \mathrm{~g} /$ bottle $)$ or both, respectively. Herbs, $\mathrm{MH}$ and BG were ground using a grinder (Molina, MIPAM, Ceské Budějovice, Czech Republic) and sieved through 0.15-0.40 mm screens. The in vitro experiment was arranged in a completely randomized design using the four diets (Control, Zn, Herbs, and $\mathrm{Zn}+$ Herbs) in fermentations with the four inocula of ruminal fluids (Control, Zn, Herbs and Zn+Herbs), with three replicates (three incubation bottles) for each diet and inoculum. The experiment was repeated three times within three consecutive days $(n=3 \times 3)$.

\section{Chemical Analysis and Measurements}

The dietary substrates were analyzed in triplicate using standard procedures for dry matter (method no. 967.03), nitrogen (method no. 968.06), crude protein (method no. 990.03) and ash (method no. 942.05) (20). The contents of acid-detergent fiber (ADF) and neutral detergent fiber (NDF) were determined (21) using the FiberCap ${ }^{\mathrm{TM}}$ 2021/2023 system (FOSS Analytical AB, Höganäs, Sweden). NDF in the forages was assayed without a thermally stable amylase and was expressed inclusive of residual ash. NDF in the concentrate was assayed using a thermally stable amylase and was expressed inclusive of residual ash. ADF was also expressed inclusive of residual ash. The chemical compositions of the dietary substrates are presented in Table $\mathbf{1}$.

The volume of accumulated total gas was determined after $24 \mathrm{~h}$ using IVGPT. For the analysis of methane, $1 \mathrm{~mL}$ of gas was collected using IVGPT and an air-tight syringe (GASTIGHT Syringes, Hamilton Bonaduz AG, Switzerland) and injected into a gas chromatograph. The VFAs and methane were analyzed on a PerkinElmer Clarus 500 gas chromatograph (Perkin Elmer, Shelton, USA) (22). Methane production in vivo was calculated based on the stoichiometric relationships between
VFA composition and methane production (23). The $\mathrm{pHs}$ of the batch cultures were measured using a $\mathrm{pH}$ meter (InoLab $\mathrm{pH}$ Level 1, Weilheim, Germany). The concentrations of ammonia$\mathrm{N}$ in the inocula were determined using the phenol-hypochlorite method (24).

\section{Analysis of Flavonoids and Phenolic Acids}

Each of the herbaceous materials $(100 \mathrm{mg}), F$. officinalis, $M$. sylvestris, A. absinthium, and $M$. chamomilla, were ground to a fine powder and extracted three times with $80 \%$ methanol $(\mathrm{MeOH})$ at $40^{\circ} \mathrm{C}$ for $30 \mathrm{~min}$. The extracts were evaporated to dryness, dissolved in $2 \mathrm{~mL}$ of Milli-Q water (acidified with $0.2 \%$ formic acid) and purified by solid-phase extraction using a 60-mg Oasis HLB 3cc Vac Cartridge (Waters Corp., Milford, USA). The Milli-Q water was prepared by an ultrapure water system (Barnstead International, Dubuque, USA). The cartridges were washed with $0.5 \% \mathrm{MeOH}$ to remove carbohydrates and then washed with $80 \% \mathrm{MeOH}$ to elute the phenolics. The phenolic fraction was re-evaporated and dissolved in $1 \mathrm{~mL}$ of $80 \%$ $\mathrm{MeOH}$ (acidified with $0.1 \%$ formic acid). The sample was then centrifuged at 23,000 $\times \mathrm{g}$ for $5 \mathrm{~min}$ before spectrometric analysis. All analyses were performed in triplicate for three independent samples and stored at $-20^{\circ} \mathrm{C}$ before analysis.

\section{Analysis of Alkaloids}

Herbal materials from $\mathrm{FO}$ were ground to a fine powder, and $100 \mathrm{mg}$ were extracted with $0.5 \mathrm{M} \mathrm{H}_{2} \mathrm{SO}_{4}$ in an ultra-bath at $25^{\circ} \mathrm{C}$ for $20 \mathrm{~min}$; the procedure was then repeated, and the filtrates were combined. The filtrates were adjusted to $\mathrm{pH}$ 9-10 using $1 \mathrm{M}$ $\mathrm{NaOH}$ and separated using $\mathrm{CHCl}_{3}$. The lower organic layer was collected, evaporated to dryness under reduced pressure and then dissolved in $80 \% \mathrm{MeOH}$ for further analysis.

\section{Ultra-High-Resolution Mass Spectrometry (UHRMS)}

The bioactive compounds of each medicinal herb (FO, MS, AA and MC) were identified using UHRMS on a Dionex UltiMate 3000RS system (Thermo Scientific, Darmstadt, Germany) with a charged aerosol detector connected to a Compact high-resolution quadrupole time-of-flight mass spectrometer (Bruker Daltonik $\mathrm{GmbH}$, Bremen, Germany). The metabolome of the mixture of herbs was chromatographically separated on a $2.1 \times 100 \mathrm{~mm}$, $2.6 \mu \mathrm{m}$, Kinetex C18 column (Phenomenex, Torrance, USA), with mobile phase A consisting of $0.1 \%(\mathrm{v} / \mathrm{v})$ formic acid (FA) in water and mobile phase B consisting of $0.1 \%(\mathrm{v} / \mathrm{v})$ FA in acetonitrile. A linear gradient from 7 to $30 \%$ of phase B in phase A over $20 \mathrm{~min}$ was used to separate the phenolic compounds, with a short $0.3 \mathrm{~min}$ calibration segment from 0 to $0.5 \mathrm{~min}$. The flow rate was $0.3 \mathrm{~mL} / \mathrm{min}$, and the column was held at $25^{\circ} \mathrm{C}$. Spectra were acquired in negative-ion mode over a mass range from $\mathrm{m} / \mathrm{z} 100$ to 1,500 with a frequency of $5 \mathrm{~Hz}$. The operating parameters of the ESI ion source were: capillary voltage, $3 \mathrm{kV}$; dry gas flow, $6 \mathrm{~L} / \mathrm{min}$; dry gas temperature, $200{ }^{\circ} \mathrm{C}$; nebulizer pressure, 0.7 bar; collision radio frequency, $700.0 \mathrm{~V}$; transfer time, $100.0 \mu \mathrm{s}$ and pre-pulse storage, $7.0 \mu \mathrm{s}$. Ultrapure nitrogen was used as the drying and nebulizer gas, and argon was used as the collision gas. The collision energy 
was set automatically from 15 to $75 \mathrm{eV}$ depending on the mass of the fragmented ion. The data were calibrated internally using sodium formate introduced into the ion source at the beginning of each separation via a $20-\mu \mathrm{L}$ loop. The spectra were processed using Bruker DataAnalysis 4.3 software (Bruker Daltonik GmbH, Bremen, Germany). The amounts of the phenolic acids in the samples were calculated as the chlorogenic acid (CAS 327-97-9, 3-caffeoylquinic acid) equivalent, and hyperoside (CAS 482-360 , quercetin 3-galactoside) was used for calculating the amounts of the flavonoids identified. Stock solutions of hyperoside and chlorogenic acid were prepared in $\mathrm{MeOH}$ at concentrations of 3.1 and $4.1 \mathrm{mg} / \mathrm{mL}$, respectively, and kept frozen until used. Calibration curves for these two compounds were constructed based on seven concentration points (from 500 to $3.9 \mu \mathrm{g} / \mathrm{mL}$ ).

The total content of alkaloids was determined as the chelidonine (CAS 476-32-4) equivalent from the calibration curves based on seven concentration points of chelidonine (from 200 to $1.2 \mu \mathrm{g} / \mathrm{mL}$ ). The alkaloids were separated using the same HPLC conditions as with the phenolic compounds, with one exception: positive-ion mode was used for the acquired spectra in auto MS/MS. All analyses were performed in triplicate.

\section{Quantification of Ruminal Microbes}

Samples for counting ciliate protozoa were fixed in equal volumes of $8 \%$ formaldehyde, and the protozoa were counted and identified microscopically as described by Williams and Coleman (25). DNA for quantifying bacteria was isolated from the ruminal samples using a Mini Bead-Beater (BioSpec, Bartlesville, USA) for cell lysis (26), followed by purification using a QIAamp DNA Stool Mini Kit (Qiagen, Hilden, Germany). DNA concentrations and qualities were measured using a NanoPhotometer ${ }^{\circledR}$ NP80 (Implen $\mathrm{GmbH}$, München, Germany). Eubacteria and archaea were quantified by real-time PCR using the PCR primers (27). The relative abundance of the 16S rRNA gene was expressed as an arbitrary unit (AU) relative to the total abundance of bacterial genes of the Control group.

\section{Histological Parameters}

Samples of fresh ruminal tissues were washed in a phosphate buffer $(0.1 \mathrm{M}, \mathrm{pH} 7.4)$, put in plastic containers and fixed in a $10 \%$ buffered FA solution as pieces of tissue spread on flat polystyrene. The fixed material was processed using a series of reagents and embedded in Paraplast PLUS paraffin blocks (Leica, Buffalo Grove, USA), which were then cut with a rotary microtome into sections $3.5 \mu \mathrm{m}$ thick. Slides with a paraffin section were automatically stained with hematoxylin and eosin (Varistain Gemini Thermo Scientific, Runcorn, UK). An Axio Lab. 1 microscope (Carl Zeiss, Jena, Germany) equipped with a Zeiss Axiocam ERc5s digital camera was used for histological evaluation. Photographs were analyzed and recorded using ZEN 2.3 (blue edition) software (Carl Zeiss Microscopy GmbH, 2011).

\section{Data Analysis}

The data were statistically analyzed using GraphPad Prism 8.3.0 (538) 2019 (GraphPad Software, Inc., San Diego, USA). Data for the parameters of ruminal fermentation and in vitro ciliate populations were analyzed using two-way analyses of variance (ANOVAs). The model included effects for diets, inocula and the diet $\times$ inoculum interaction. Statistical analysis of the hematological parameters used an ANOVA as a repeatedmeasure mixed model that represented the four animal groups and the sampling days. In vivo data were evaluated by multiple comparisons of one-way ANOVAs using Dunnett's multiple comparisons test. The total and differential counts of the ruminal ciliates were analyzed using the non-parametric Kruskal-Wallis test. The effects were determined to be significant at $P<0.05$.

\section{RESULTS}

\section{Phytochemical Substances in the Medicinal Herbs}

The phytochemical substances in FO consisted of $12.211 \mathrm{~g} / \mathrm{kg}$ DM flavonoids, $3.961 \mathrm{~g} / \mathrm{kg}$ DM phenolic acids (Table 2) and 6.015 $\mathrm{g} / \mathrm{kg}$ DM alkaloids (Table 3). The phytochemical substances in MS consisted of $6.479 \mathrm{~g} / \mathrm{kg}$ DM flavonoids and $0.654 \mathrm{~g} / \mathrm{kg} \mathrm{DM}$ phenolic acids (Table 2). The phytochemical substances in AA consisted of $0.349 \mathrm{~g} / \mathrm{kg}$ DM flavonoids and $6.482 \mathrm{~g} / \mathrm{kg} \mathrm{DM}$ phenolic acids (Table 2). The phytochemical substances in MC consisted of $2.442 \mathrm{~g} / \mathrm{kg}$ DM flavonoids and $12.084 \mathrm{~g} / \mathrm{kg} \mathrm{DM}$ phenolic acids (Table 2).

\section{Effect of Dietary Substrates on Ruminal Fermentation in vitro}

The effects of the dietary substrates and inocula on the parameters of ruminal fermentation in vitro are presented in Table 4. The inocula of the donor animals affected the values of all parameters of fermentation $(P<0.001)$. Diet significantly affected total gas $(P<0.046)$ and methane $(P$ $<0.001)$ production. The amount of $n$-butyrate also varied among the dietary treatments $(P<0.001)$, with $n$-butyrate concentrations higher for the $\mathrm{Zn}$ and $\mathrm{Zn}+$ Herbs groups than the Control group. The different ruminal inocula also significantly affected the protozoal populations of the lambs in vitro (Table 5).

\section{Effects of Zinc and Herbal Diets on Ruminal Fermentation and Microbiota in the Lambs}

The dietary supplements did not significantly affect $(P>$ 0.05 ) the parameters of ruminal fermentation in the lambs (Table 6). The number of ruminal ciliated protozoa, expressed as counts per gram of wet ruminal content or as counts per gram of dry ruminal content in the lambs did not differ significantly $(P>0.05)$ between the groups (Table 7). The lambs contained three ciliate populations. Nineteen animals (68\%) had mixed A-B type populations, consisting of Polyplastron multivesiculatum (100\% prevalence), Epidinium ecaudatum caudatum ( $84 \%$ prevalence), and Ophryoscolex caudatus tricoronatus (53\% prevalence), seven animals (25\%) had A type populations, consisting of $P$. multivesiculatum (100\% prevalence) and O. caudatus tricoronatus $(29 \%$ prevalence), and two animals (7\%) had B type populations, consisting of E. ecaudatum caudatum (100\% prevalence) 
TABLE 2 | Concentrations of the main bioactive compounds in medicinal herbs ( $g / k g ~ D M)$.

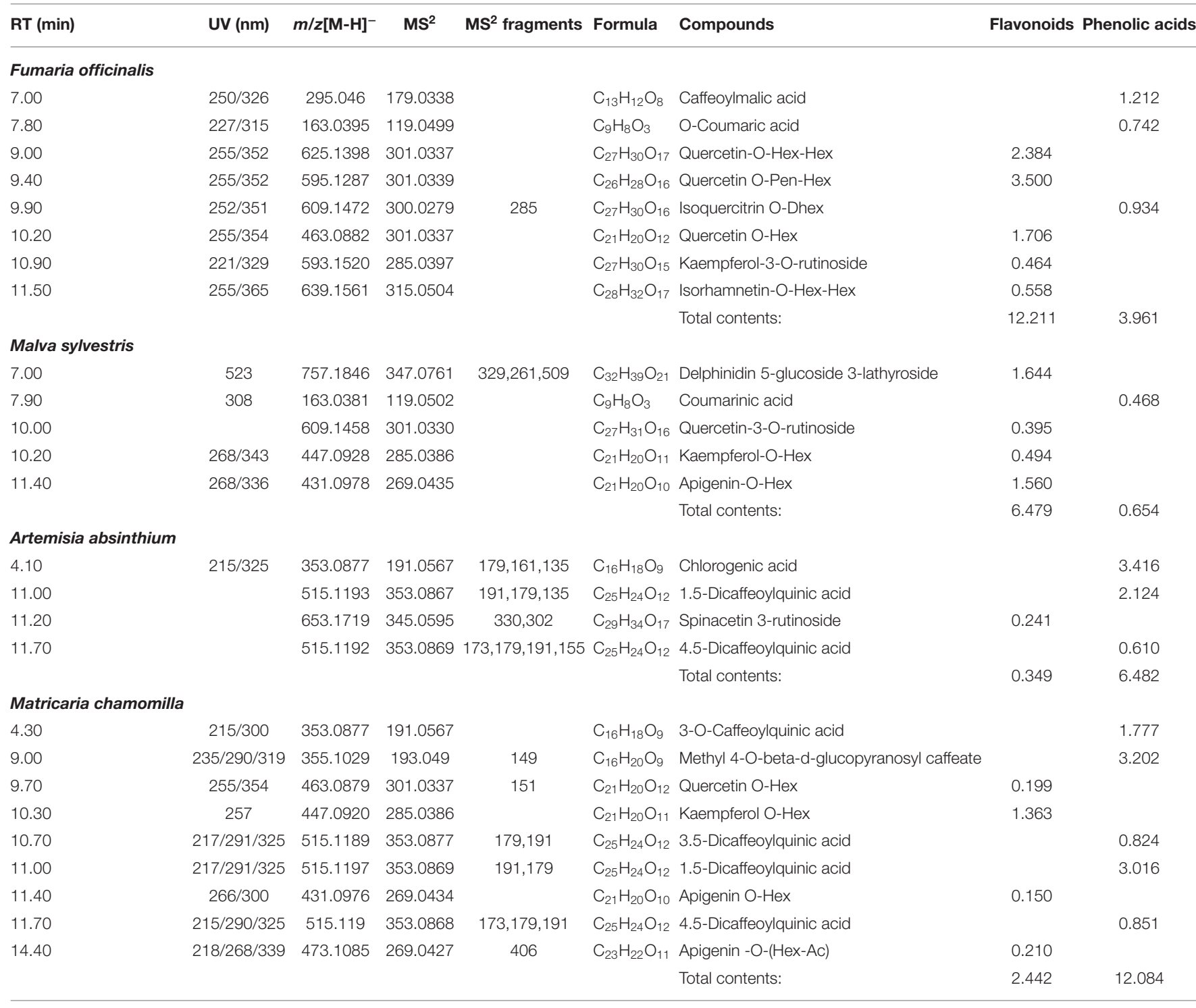

but no Polyplastron or Ophryoscolex. All animals had Dasytricha ruminantium, Isotricha intestinalis, I. prostoma, and Entodinium spp.

The total bacterial populations (Figure 1A) were significantly lower $(P<0.05)$ for the $\mathrm{Zn}$ and $\mathrm{Zn}+$ Herbs groups than the Control group, but the relative abundances of Ruminococcus albus (Figure 1C), Streptococcus bovis (Figure 1D) and Butyrivibrio proteoclasticus (Figure 1E) were significantly higher in the group fed the $\mathrm{Zn}$ diets. In contrast, the relative abundance of Ruminococcus flavefaciens (Figure 1K) was significantly lower $(P<0.05)$ in the $\mathrm{Zn}$ than the Control group. The relative abundance of Fibrobacter succinogenes (Figure 1F) was significantly lower $(P<0.05)$ in the Herbs than the Control group. The other microbial populations, such as those of Archaea (Figure 1B), Butyrivibrio fibrisolvens (Figure 1G), Prevotella (Figure 1H), Clostridium aminophilum (Figure 1I) and Megasphaera elsdenii (Figure 1J), did not differ significantly $(P>0.05)$ among the groups.

\section{Hematological Parameters}

The count of red blood cells, hemoglobin level and hematocrit were not significantly influenced by time, treatment or the treatment $\times$ time interaction $(P>0.05)$ (Table 8). Time significantly affected the mean corpuscular volumes $(P<0.001)$. Treatment and time significantly affected neutrophil levels $(P<$ $0.05)$, and time significantly affected the counts of lymphocytes and eosinophils $(P<0.001$ and $<0.05$, respectively).

\section{Effects of Diet on the Morphological Parameters of the Ruminal Papillae}

The histology of the ruminal papillae of the Control and $\mathrm{Zn}$ groups were normal (Figures 2A,B). The sizes of the papillae 
TABLE 3 | Concentrations of the main alkaloids in Fumaria officinalis ( $/ \mathrm{kg} \mathrm{DM})$.

\begin{tabular}{|c|c|c|c|c|c|c|c|}
\hline $\mathrm{RT}$ (min) & UV (nm) & $m / z[M-H]^{-}$ & MS $^{2}$ & $\mathrm{MS}^{2}$ fragments & Formula & Compounds & Alkaloids \\
\hline 7.70 & 272 & 354.1366 & 305.0811 & $279,233,323,336$ & $\mathrm{C}_{20} \mathrm{H}_{19} \mathrm{NO}_{5}$ & Parfumine & 0.884 \\
\hline 8.40 & 280 & 328.1572 & 265.0865 & $237,297,313,178$ & $\mathrm{C}_{19} \mathrm{H}_{21} \mathrm{NO}_{4}$ & Cularimine & 0.102 \\
\hline 8.50 & 288 & 370.1678 & 291.1029 & $263,352,337$ & $\mathrm{C}_{21} \mathrm{H}_{23} \mathrm{NO}_{5}$ & Fumaricine & 0.102 \\
\hline 8.90 & 285 & 326.1410 & 311.1172 & $277,294,251,178$ & $\mathrm{C}_{19} \mathrm{H}_{19} \mathrm{NO}_{4}$ & Cheilanthifoline & 0.231 \\
\hline 9.20 & 286 & 354.1360 & 275.0713 & 336,247 & $\mathrm{C}_{20} \mathrm{H}_{19} \mathrm{NO}_{5}$ & Chelidonine & 0.154 \\
\hline 10.60 & 288 & 354.1727 & 206.1139 & $275,311,338,292$ & $\mathrm{C}_{21} \mathrm{H}_{23} \mathrm{NO}_{4}$ & Protopine type & 0.367 \\
\hline 10.80 & 271 & 352.1193 & 279.0647 & $309,321,263,251$ & $\mathrm{C}_{20} \mathrm{H}_{17} \mathrm{NO}_{5}$ & Fumariline & 1.728 \\
\hline \multirow[t]{2}{*}{11.20} & 288 & 324.1230 & 249.0764 & $307,277,219,176$ & $\mathrm{C}_{19} \mathrm{H}_{17} \mathrm{NO}_{4}$ & Stylopine & 0.785 \\
\hline & & & & & & Total contents: & 6.015 \\
\hline
\end{tabular}

$m / z$, mass-to-charge ratio.

TABLE 4 | Effect of ruminal inocula and diets on the fermentation parameters in vitro $(N=9)$.

\begin{tabular}{|c|c|c|c|c|c|c|c|c|c|c|c|c|c|c|}
\hline Inoculum & Diet & $\mathrm{pH}$ & $\begin{array}{l}\mathrm{NH}_{3}-\mathrm{N} \\
(\mathrm{mg} / \mathrm{L})\end{array}$ & $\begin{array}{c}\text { Gas } \\
(\mathrm{mL} / \mathrm{g})\end{array}$ & $\begin{array}{c}\mathrm{CH}_{4} \\
(\mathrm{mM})\end{array}$ & $\begin{array}{c}\text { IVDMD } \\
\text { (g/kg DM) }\end{array}$ & $\begin{array}{l}\text { VFA } \\
\text { mM }\end{array}$ & $\underset{\mathrm{mol} \%}{\mathrm{~A}}$ & $\begin{array}{c}\mathbf{P} \\
\mathrm{mol} \%\end{array}$ & $\begin{array}{c}\mathrm{iB} \\
\mathrm{mol} \%\end{array}$ & $\begin{array}{c}\mathrm{nB} \\
\mathrm{mol} \%\end{array}$ & $\begin{array}{c}\mathrm{iV} \\
\mathrm{mol} \%\end{array}$ & $\begin{array}{c}\mathrm{nV} \\
\mathrm{mol} \%\end{array}$ & $\begin{array}{c}\mathrm{nC} \\
\mathrm{mol} \%\end{array}$ \\
\hline \multirow[t]{4}{*}{ Control } & Control & 6.84 & 217 & 229 & 2.74 & 574 & 46.7 & 66.8 & 14.9 & 0.97 & 13.9 & 1.81 & 1.38 & 0.28 \\
\hline & $\mathrm{Zn}$ & 6.92 & 192 & 222 & 2.80 & 518 & 43.9 & 66.5 & 15.2 & 0.84 & 14.3 & 1.60 & 1.37 & 0.25 \\
\hline & Herbs & 6.91 & 214 & 240 & 2.88 & 581 & 46.6 & 67.0 & 15.0 & 0.85 & 13.8 & 1.71 & 1.36 & 0.31 \\
\hline & Zn+Herbs & 6.87 & 198 & 227 & 2.97 & 502 & 46.3 & 66.8 & 15.3 & 0.73 & 14.0 & 1.54 & 1.42 & 0.33 \\
\hline \multirow[t]{4}{*}{$\mathrm{Zn}$} & Control & 6.96 & 305 & 233 & 3.06 & 341 & 43.8 & 65.2 & 15.3 & 1.55 & 13.0 & 2.79 & 1.75 & 0.40 \\
\hline & $\mathrm{Zn}$ & 6.96 & 301 & 218 & 2.62 & 325 & 41.1 & 64.5 & 15.6 & 1.55 & 13.6 & 2.70 & 1.74 & 0.37 \\
\hline & Herbs & 6.91 & 330 & 250 & 3.61 & 347 & 45.6 & 65.3 & 15.5 & 1.57 & 12.8 & 2.73 & 1.77 & 0.34 \\
\hline & Zn+Herbs & 6.82 & 273 & 231 & 3.31 & 306 & 44.0 & 65.3 & 15.8 & 1.27 & 13.2 & 2.41 & 1.69 & 0.34 \\
\hline \multirow[t]{4}{*}{ Herbs } & Control & 6.99 & 248 & 218 & 2.66 & 525 & 36.2 & 66.9 & 16.1 & 1.10 & 11.9 & 2.16 & 1.59 & 0.25 \\
\hline & $\mathrm{Zn}$ & 6.98 & 214 & 198 & 1.73 & 492 & 37.8 & 65.8 & 15.9 & 1.08 & 13.1 & 2.11 & 1.65 & 0.28 \\
\hline & Herbs & 6.95 & 222 & 216 & 2.66 & 554 & 41.5 & 66.8 & 16.4 & 1.07 & 11.9 & 2.05 & 1.55 & 0.26 \\
\hline & Zn+Herbs & 6.98 & 216 & 211 & 2.47 & 515 & 39.5 & 66.3 & 16.2 & 1.05 & 12.7 & 1.95 & 1.58 & 0.29 \\
\hline \multirow[t]{4}{*}{ Zn+Herbs } & Control & 7.06 & 182 & 184 & 2.68 & 585 & 35.0 & 65.7 & 16.7 & 1.11 & 12.8 & 1.95 & 1.54 & 0.22 \\
\hline & $\mathrm{Zn}$ & 7.05 & 184 & 173 & 2.28 & 575 & 32.5 & 64.7 & 16.3 & 1.07 & 14.1 & 1.94 & 1.66 & 0.23 \\
\hline & Herbs & 7.04 & 204 & 178 & 2.76 & 622 & 35.9 & 65.8 & 16.6 & 1.08 & 12.9 & 1.93 & 1.57 & 0.21 \\
\hline & Zn+Herbs & 7.06 & 197 & 180 & 2.52 & 571 & 34.1 & 65.0 & 16.7 & 1.01 & 13.6 & 1.83 & 1.69 & 0.23 \\
\hline SEM & & 0.037 & 24.4 & 8.65 & 0.186 & 39.7 & 2.60 & 0.564 & 0.364 & 0.104 & 0.289 & 0.199 & 0.065 & 0.028 \\
\hline \multicolumn{15}{|c|}{ Significance of the effects: } \\
\hline Diet & & 0.512 & 0.606 & 0.046 & 0.001 & 0.316 & 0.256 & 0.159 & 0.857 & 0.211 & 0.001 & 0.478 & 0.771 & 0.730 \\
\hline Inoculum & & 0.001 & 0.001 & 0.001 & 0.001 & 0.001 & 0.001 & 0.001 & 0.001 & 0.001 & 0.001 & 0.001 & 0.001 & 0.001 \\
\hline Diet $x$ inoculum & & 0.457 & 0.985 & 0.942 & 0.299 & 0.996 & 0.999 & 0.999 & 0.997 & 0.983 & 0.877 & 0.999 & 0.877 & 0.600 \\
\hline
\end{tabular}

IVDMD, In vitro dry matter digestibility; VFA, Volatile fatty acids; A, Acetate; P, Propionate; iB, Iso-butyrate; $n B, N$-butyrate; iV, Iso-valerate; $n V, N$-valerate; $n C, N$-caproate.

varied in the Herbs group (Figure 2C), and both the type and number of keratinized epithelial cells varied in the Zn+Herbs group (Figure 2D). A focally mixed infiltration of inflammatory cells in individual papillae within the epithelial layer was observed in two animals fed the Herbs diet and within the lamina propria in most animals fed the $\mathrm{Zn}+$ Herbs diet.

\section{DISCUSSION}

Our previous results indicated that the addition of zinc to the diet of lambs did not negatively influence microbial activity in the rumen or large intestine (4). A mixture of herbs containing $\mathrm{FO}, \mathrm{MS}, \mathrm{AA}$, and $\mathrm{MC}$ also possessed strong ruminal antioxidant capacity and reduced gastrointestinal concentrations of methane and ammonia in vitro (15). To the best of our knowledge, however, the present experiment is the first to determine the interactions between supplementations with organic zinc and herbs by combining phytochemical, physiological, microbiological and histopathological measurements in the rumen of lambs.

The phytochemical substances in FO consisted of flavonoids, alkaloids and phenolic acids. There were mainly quercetin-OHex-Hex (2.384 g/kg DM), quercetin O-Pen-Hex ( $3.5 \mathrm{~g} / \mathrm{kg} \mathrm{DM})$, fumariline $(1.728 \mathrm{~g} / \mathrm{kg} \mathrm{DM})$, fumaricine $(0.102 \mathrm{~g} / \mathrm{kg} \mathrm{DM})$, and caffeoylmalic acid $(1.212 \mathrm{~g} / \mathrm{kg} \mathrm{DM})$. The flavonoid (flavonol) quercetin possesses various antioxidative and anti-inflammatory 
TABLE 5 | Effect of ruminal inocula and diets on the protozoal population in vitro $(N=9)$.

\begin{tabular}{|c|c|c|c|c|c|c|}
\hline Inoculum & Diet & $\begin{array}{c}\text { Dasytricha ruminantium } \\
\qquad(\mathrm{n} / \mathrm{mL})\end{array}$ & $\begin{array}{l}\text { Isotricha spp. } \\
\quad(\mathrm{n} / \mathrm{mL})\end{array}$ & $\begin{array}{l}\text { Polyplastron multivesiculatum } \\
\qquad(\mathrm{n} / \mathrm{mL})\end{array}$ & $\begin{array}{l}\text { Entodinium spp. } \\
\qquad\left(10^{3} / \mathrm{mL}\right)\end{array}$ & $\begin{array}{c}\text { Total protozoa } \\
\left(10^{3} / \mathrm{mL}\right)\end{array}$ \\
\hline \multirow[t]{3}{*}{ Control } & Control & 850 & 1,010 & 330 & 368 & 378 \\
\hline & Herbs & 1,450 & 1,230 & 480 & 329 & 338 \\
\hline & $\mathrm{Zn}+$ Herbs & 2,510 & 1,280 & 570 & 334 & 343 \\
\hline & Herbs & 2,430 & 1,830 & 710 & 425 & 430 \\
\hline & $\mathrm{Zn}+$ Herbs & 2,750 & 1,900 & 690 & 395 & 401 \\
\hline \multirow[t]{3}{*}{ Herbs } & Control & 3,270 & 800 & 310 & 321 & 326 \\
\hline & $\mathrm{Zn}$ & 3,730 & 640 & 250 & 292 & 297 \\
\hline & Herbs & 3,204 & 530 & 210 & 314 & 318 \\
\hline $\mathrm{Zn}+$ Herbs & $\mathrm{Zn}+$ Herbs & 2,720 & 1,670 & 250 & 329 & 335 \\
\hline SEM & & 111.5 & 81.8 & 29.0 & 9.1 & 9.2 \\
\hline \multicolumn{7}{|c|}{ Significance of the effects: } \\
\hline \multicolumn{2}{|l|}{ Diet } & 0.073 & 0.734 & 0.563 & 0.982 & 0.982 \\
\hline \multicolumn{2}{|l|}{ Inoculum } & $<0.001$ & $<0.001$ & $<0.001$ & 0.004 & 0.004 \\
\hline \multicolumn{2}{|c|}{ Diet $x$ inoculum } & 0.799 & 0.933 & 0.870 & 0.979 & 0.982 \\
\hline
\end{tabular}

TABLE 6 | Effect of zinc and herbs on the parameters of ruminal fermentation in the lambs $(N=7)$.

\begin{tabular}{lcccccc}
\hline Item & Control & Zn & Herbs & Zn+Herbs & SD & $P$-value \\
\hline pH & 6.84 & 6.95 & 6.89 & 7.05 & 0.245 & 0.468 \\
Ammonia (mg/L) & 110 & 129 & 121 & 102 & 38.5 & 0.629 \\
Methane (mM) & 0.376 & 0.382 & 0.378 & 0.381 & 0.071 & 0.832 \\
Total VFA (mM) & 53.9 & 42.6 & 47.2 & 37.3 & 13.9 & 0.191 \\
Acetate (mol\%) & 69.1 & 69.1 & 69.8 & 68.3 & 2.04 & 0.663 \\
Propionate (mol\%) & 13.8 & 13.9 & 14.5 & 14.5 & 1.55 & 0.753 \\
n-Butyrate (mol\%) & 13.5 & 12.1 & 11.8 & 12.5 & 1.59 & 0.240 \\
iso-Butyrate (mol\%) & 1.03 & 1.73 & 1.10 & 1.65 & 0.879 & 0.356 \\
n-Valerate (mol\%) & 0.914 & 0.910 & 0.936 & 1.03 & 0.221 & 0.717 \\
iso-Valerate (mol\%) & 1.33 & 2.00 & 1.51 & 1.77 & 0.822 & 0.478 \\
n-Caproate (mol\%) & 0.300 & 0.267 & 0.263 & 0.204 & 0.119 & 0.546 \\
A:P & 5.10 & 5.04 & 4.83 & 4.77 & 0.567 & 0.673 \\
\hline
\end{tabular}

effects and metabolic health-promoting properties (28). Both isoquinoline alkaloids fumariline and fumaricine contribute to the important pharmacological activities of FO (29). The phenolic compound caffeoylmalic acid can protect protein from degradation in ruminants that use forage protein (30). The concentrations of the flavonoids, delphinidin 5-glucoside 3-lathyroside (1.644 $\mathrm{g} / \mathrm{kg} \mathrm{DM})$ and apigenin-O-Hex (1.56 $\mathrm{g} / \mathrm{kg} \mathrm{DM})$, were highest in MS. The health-promoting effect of apigenin O-Hex, which has therapeutic potential, has been reported (31), but flavonoids generally possess beneficial biochemical properties with predominantly protective roles
TABLE $7 \mid$ Effects of zinc and herbs on the number of ruminal ciliated protozoa in the lambs $(N=7)$.

\begin{tabular}{|c|c|c|c|c|c|c|}
\hline Genus/treatment & Control & $\mathrm{Zn}$ & Herbs & $\mathrm{Zn}+$ Herbs & SD & $P$-value \\
\hline $\begin{array}{l}\text { Dasytricha sp. (c/g } \\
\text { wRC) }\end{array}$ & 4,754 & 5,28 & 6,717 & 8,619 & 5,004 & 0.433 \\
\hline Isotricha spp. (c/g wRC) & 2,280 & 3,132 & 2,656 & 2,043 & 1,581 & 0.417 \\
\hline $\begin{array}{l}\text { Polyplastron spp. (c/g } \\
\text { WRC) }\end{array}$ & 2,571 & 2,723 & 2,311 & 663 & 1,445 & 0.064 \\
\hline Epidinium spp. (c/g wRC) & 15,905 & 160 & 3,055 & 13,612 & 9,558 & 0.662 \\
\hline $\begin{array}{l}\text { Entodinium spp. (c/g } \\
\text { wRC) }\end{array}$ & 465,316 & 485,455 & 412,898 & $8 \quad 457,362$ & 93,530 & 0.392 \\
\hline Total protozoa (c/g wRC) & 489,413 & 500,892 & 427,987 & $7 \quad 483,593$ & 95,191 & 0.454 \\
\hline Dasytricha sp. (c/g DM) ${ }^{b}$ & 492 & 609 & 701 & 904 & 503 & 0.529 \\
\hline Isotricha spp. (c/g DM) & 301 & 401 & 327 & 241 & 228 & 0.275 \\
\hline $\begin{array}{l}\text { Polyplastron spp. (c/g } \\
\text { DM) }\end{array}$ & 234 & 333 & 291 & 75 & 216 & 0.133 \\
\hline Epidinium spp. (c/g DM) & 2,258 & 18 & 274 & 1,566 & 1,123 & 0.044 \\
\hline Entodinium spp. (c/g DM) & 63,146 & 59,933 & 49,355 & 52,791 & 17,298 & 0.490 \\
\hline Total protozoa (c/g DM) & 66,430 & 61,914 & 50,987 & 55,729 & 17,936 & 0.400 \\
\hline
\end{tabular}

${ }^{a}$ Expressed as count (c) per gram of wet ruminal content (WRC); ${ }^{b}$ Expressed as count per gram of dry matter (DM) of ruminal content.

against many diseases (32). The phytochemical substances in AA consisted mainly of phenolic acids, including chlorogenic acid (3.416 g/kg DM) and 1,5-dicaffeoylquinic acid (2.124 g/kg DM), which possess antibacterial, anthelmintic, anti-inflammatory and antioxidant biological activities in vitro and in vivo $(33,34)$. 

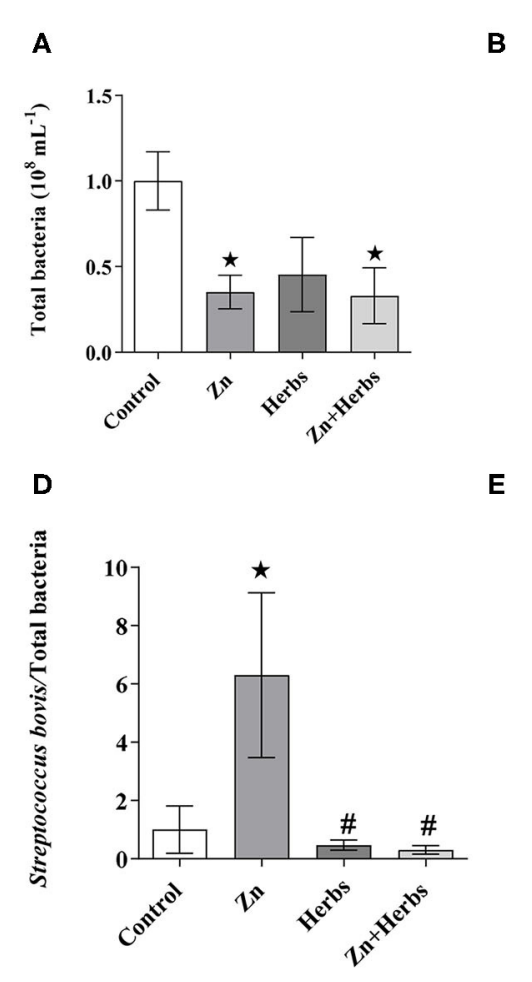

G

H
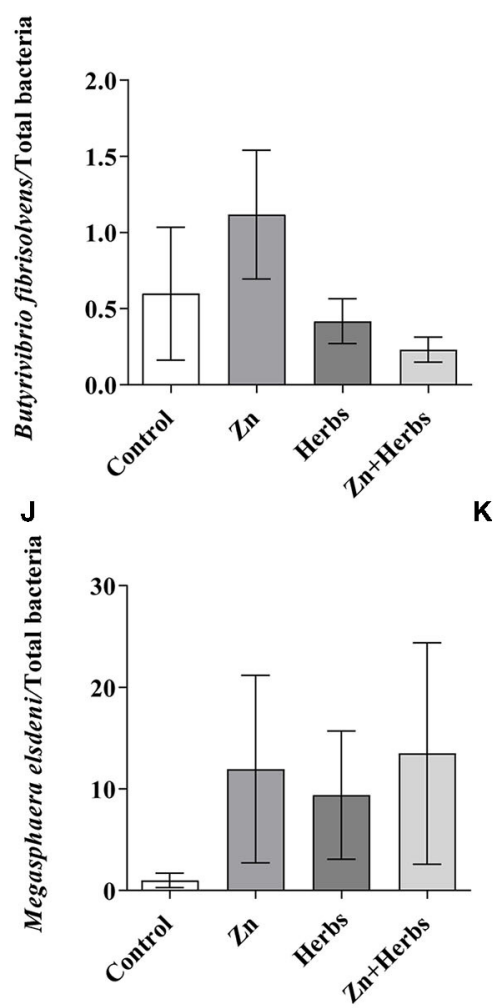

(2)

K
B

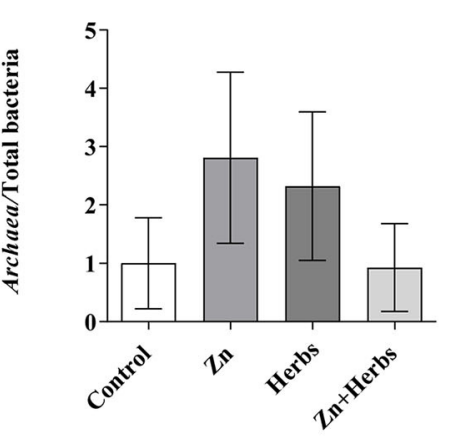

E

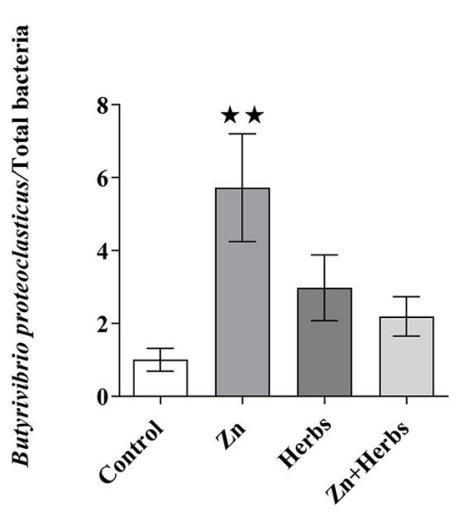

c
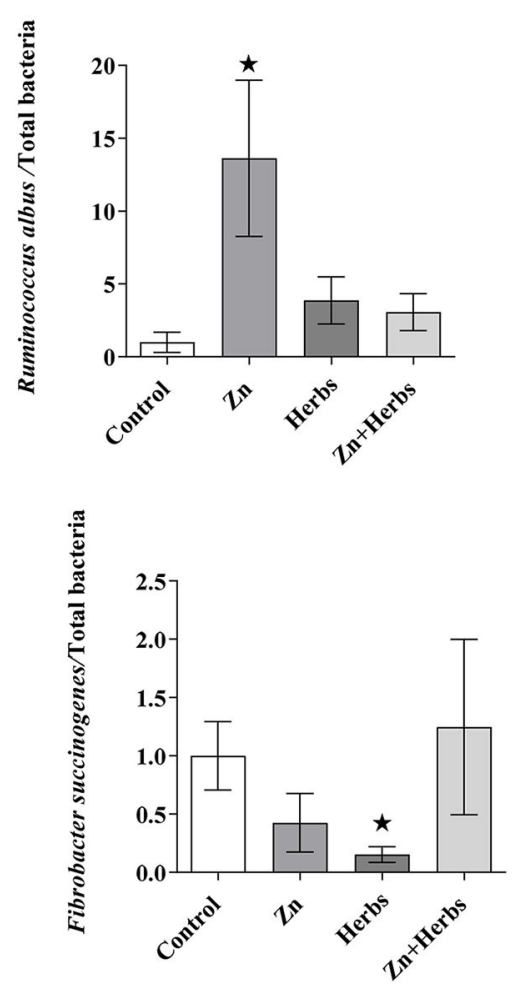
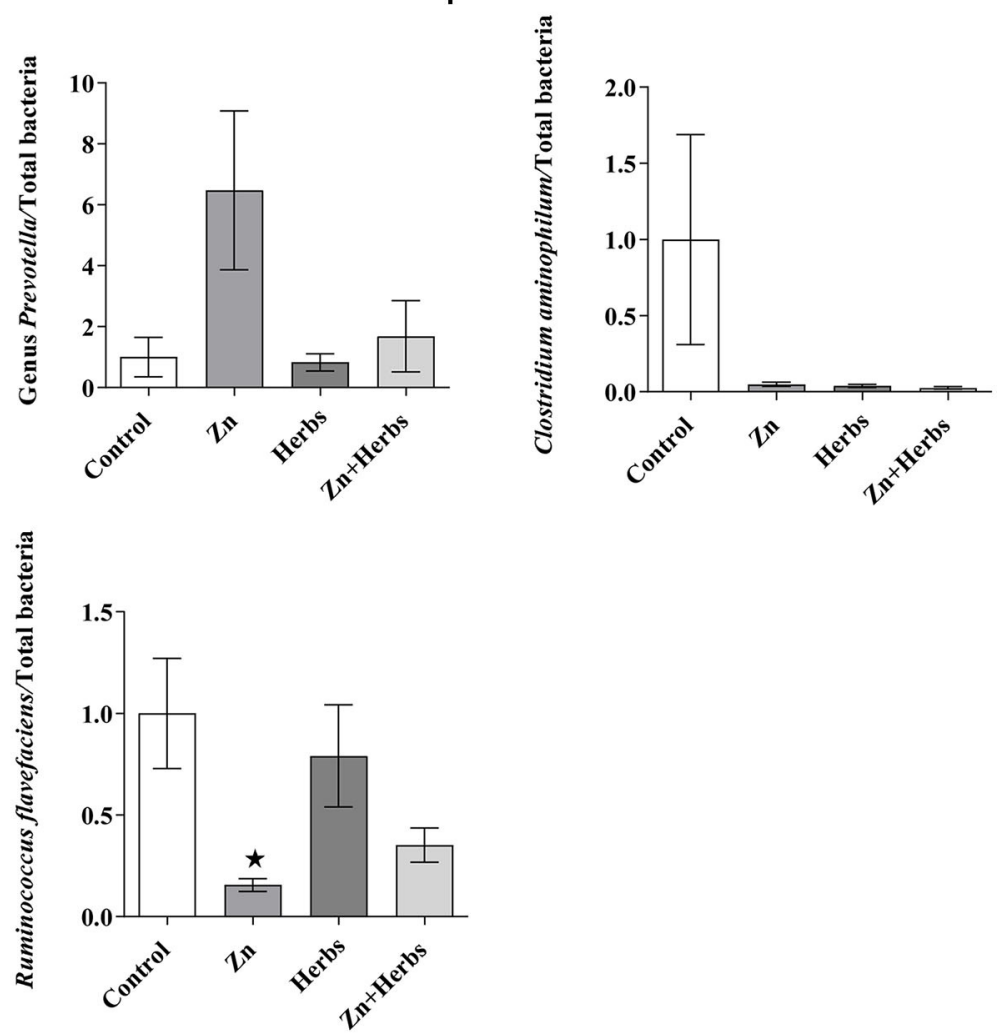

FIGURE 1 | Effects of the Control, Zn, Herbs, and Zn+Herbs diets on the relative abundance of the 16S rRNA gene (expressed relative to the total abundance of bacterial genes in the Control group) of the ruminal bacterial population for (A) total bacteria, (B) Archaea, (C) Ruminococcus albus, (D) Streptococcus bovis, (E) Butyrivibrio proteoclasticus, (F) Fibrobacter succinogenes, (G) Butyrivibrio fibrisolvens, (H) Prevotella, (I) Clostridium aminophilum, (J) Megasphaera elsdeni, and (K) Ruminococcus flavefaciens. ${ }^{\star} P<0.05$ and ${ }^{\star \star} P<0.01$ relative to the Control group; ${ }^{\#} P<0.05$ relative to the Zn group. 
TABLE 8 | Effects of zinc and herbs on the hematological parameters of the lambs $(N=7)$.

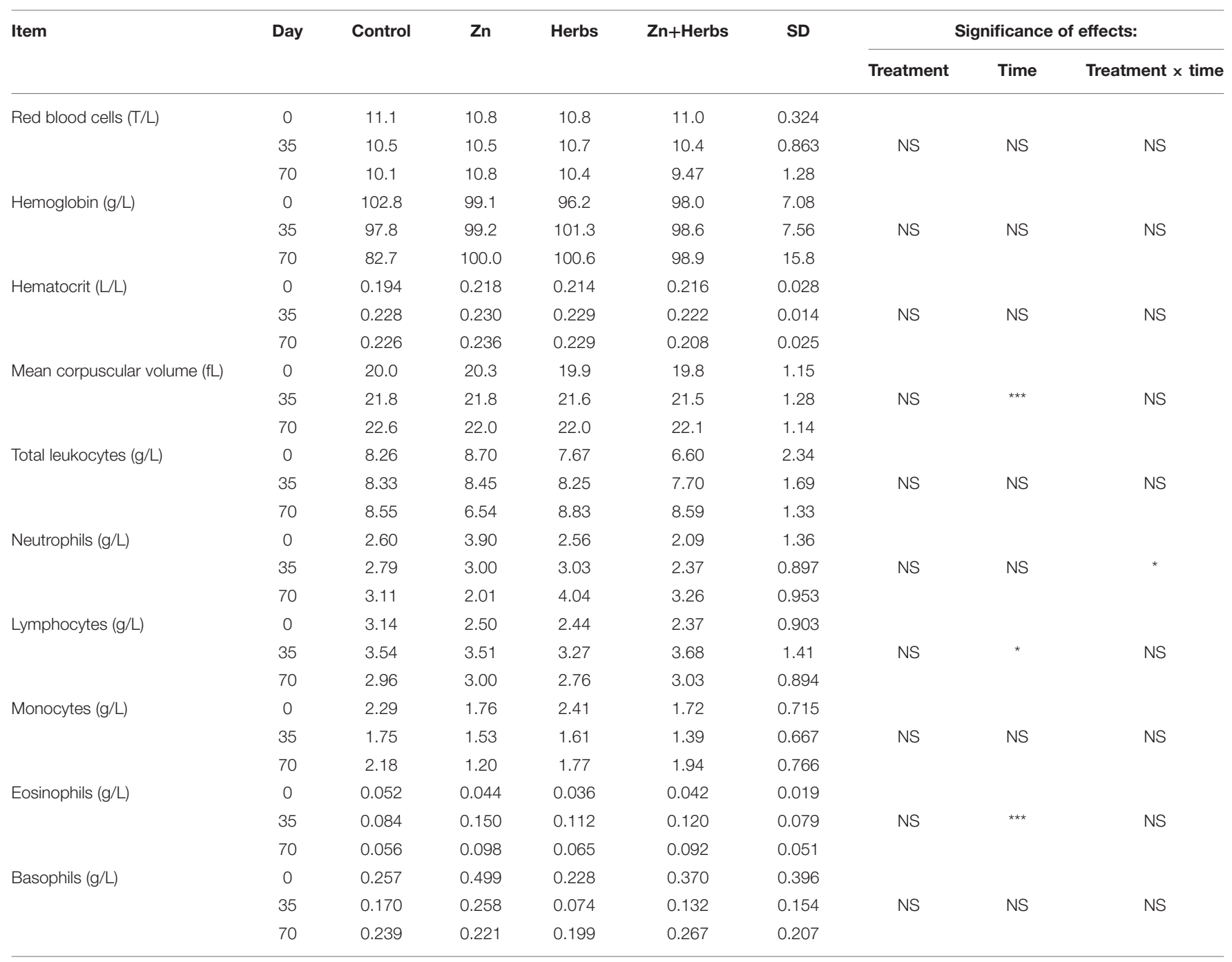

${ }^{*} P<0.05,{ }^{* *} P<0.01,{ }^{* * \star} P<0.001$.

Similarly, MC contained phenolic acids (12.084 g/ $/ \mathrm{kg}$ DM), mainly methyl 4 -O-beta-d-glucopyranosylcaffeate $(3.202 \mathrm{~g} / \mathrm{kg}$ $\mathrm{DM})$, with well-known antioxidant activity (35), and contained derivatives of caffeoylquinic acid, which have anti-inflammatory biological activities (36).

The mixture of the dry medicinal herbs had high concentrations of flavonoids, especially quercetin $(7.6 \mathrm{mg} / \mathrm{g}$ DM) (15). Quercetin, after intraruminal application (10 and $50 \mathrm{mg} / \mathrm{kg} \mathrm{BW}$ ) in cows, is a flavonoid extensively degraded by ruminal microbiota without negative effects on ruminal fermentation (37). The administration of some flavonoids with antimicrobial properties, however, can affect the gastrointestinal microbiota. The $\mathrm{Zn}$, Herbs and $\mathrm{Zn}+$ Herbs diets under in vitro conditions in our study only affected the levels of total gas, methane and $n$-butyrate. The reported effects of flavonoids as potential dietary additives for ruminants (e.g., quercetin, myricetin, kaempferol, and rutin) have been inconsistent, due mainly to their potential antimicrobial effects (38-40).
The in vitro ruminal inocula (Table 5), however, significantly affected all parameters of fermentation and species of protozoa. The effects of the inocula could be ascribed to the diverse ruminal ciliate populations and companion bacterial populations in the animals. Table 5 presents the number of protozoa in each group. Not all treatment groups, however, contained Ophryoscolex and Epidinium. The mixed A-B type ciliate population was also prevalent (19 animals). This finding probably indicates a gradual change from the $\mathrm{B}$ type population to the dominant A type population in the lambs, because Polyplastron feeds on Epidinium until it disappears from the ciliate population (25). The inocula had significant effects, mainly on Dasytricha species, probably caused by the long-term dietary supplementation with zinc or herbs, which can influence the composition of the eubacterial community and the enzymatic activities of ruminal microorganisms, especially amylolytic and cellulolytic enzymes $(41,42)$.

The $\mathrm{Zn}$, Herbs and $\mathrm{Zn}+$ Herbs diets did not significantly affect the parameters of fermentation or the protozoal populations in 

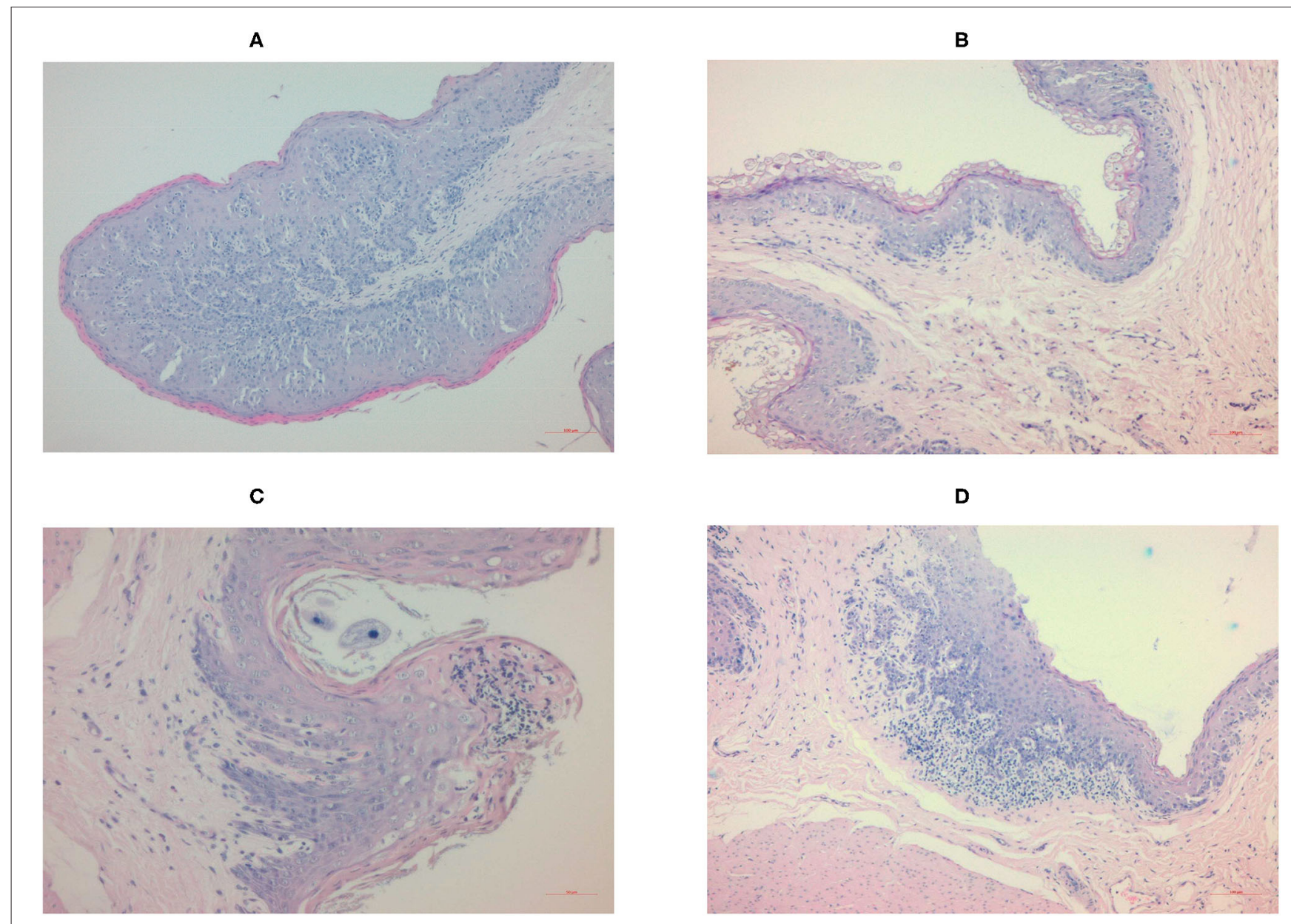

FIGURE 2 | Histology of the ruminal papillae of the lambs in the (A) Control, (B) Zn, (C) Herbs, and (D) Zn+Herbs groups. The papillae are stained with hematoxylin-eosin and viewed using a $10 \times$ objective lens.

the lambs. This finding probably indicates relatively low contents of antimethanogenic phytochemical substances or the adaptation of the microbiota to both herbal $(43,44)$ and/or zinc (45) diets. Herbal diets can influence the ruminal microbiome, the kinetics of fermentation and the response and adaptation to antimethanogenic compounds and diets that sometimes lead to the inconsistent efficacies of phytochemical substances (46). $\mathrm{Zn}$ is also involved in a wide assortment of physiological processes, so nutrient digestibility may be affected by supplemental $\mathrm{Zn}$, which is incorporated into enzymes throughout the body and is critical for most metabolic processes in ruminants (47). Zinc in the diet of ruminants can substantially influence ruminal fermentation $(48,49)$. Low doses of zinc $(20-70 \mathrm{mg} \mathrm{Zn} / \mathrm{kg}$ diet) only weakly affect ruminal fermentation $(4,10)$, but higher doses $(250-$ $1,142 \mathrm{mg} \mathrm{Zn} / \mathrm{kg}$ diet) can affect ruminal protozoal populations and protein degradation (50). The beneficial effects of zinc (i.e., its antioxidant, anti-inflammatory and antiapoptotic properties) strongly depend on both the source and concentration of the zinc, even though zinc retention in lambs can be similar regardless of these factors (47), and too much or too little zinc in diets can have the opposite effect $(51,52)$.
The amount of starch in all our diets was similar, so the diets probably similarly influenced the efficiency of the growth of the majority of the ruminal ciliates (53). Total bacteria, however, were lower in the $\mathrm{Zn}$ and $\mathrm{Zn}+$ Herbs groups than the Control group. The relative abundances of the cellulolytic bacterium $R$. albus, the amylolytic bacterium S. bovis and the polysaccharidedegrading bacterium $B$. proteoclasticus were higher, and the abundance of the cellulolytic bacterium $R$. flavefaciens was lower in the $\mathrm{Zn}$ group than the other groups. Some bacterial species were probably enriched by $\mathrm{Zn}$ supplementation at the expense of total bacterial abundance (45). These changes in total bacteria and the relative abundance of some bacteria in the $\mathrm{Zn}$ group were not accompanied by changes in VFAs in ruminal fermentation in vivo. This finding indicates a direct effect on ruminal microbiota due to an interaction with crude protein rather than to the benefits of $\mathrm{Zn}$ supplementation, which is exerted solely on the host organism (8). The lower relative abundance of cellulolytic bacteria (i.e., F. succinogenes and R. flavefaciens) in the $\mathrm{Zn}$ or $\mathrm{Zn}+$ Herbs groups, respectively, however, probably also lowered the digestibility of the substrate in vitro in these groups (Table 4). The ruminal microbiota may have a specific requirement for zinc 
supplementation that does not cause a major shift in the ruminal bacterial community and does not have negative consequences for digestion or animal health (45). Some bacterial phylotypes can also contribute to differences in feed efficiency and host productivity and can or need not depend on the diet (54). The relative abundance of the starch-fermenting bacterium $S$. bovis was lower in the Herbs and $\mathrm{Zn}+$ Herbs groups than the $\mathrm{Zn}$ group, but the relative abundance of the cellulolytic bacterium $F$. succinogenes was lower in the Herbs and $\mathrm{Zn}+$ Herbs groups than the Control group, probably due to the antimicrobial activity of some flavonoids, which can increase competition among bacteria $(40,55)$.

Ruminal VFAs are absorbed through the ruminal epithelium, and the rate of absorption depends on the VFA concentration, the surface area of the ruminal papillae and the availability of transport proteins $(56,57)$. The ruminal papillae of the lambs in the Control and $\mathrm{Zn}$ groups were histologically normal, with diverse sizes of the papillae and the type and number of keratinized epithelial cells. The external layer of vesiculated keratinized cells of the ruminal epithelium is an absorption barrier to the transport of molecules from the rumen to the blood (58). The stratum corneum in the $\mathrm{Zn}$ group contained several layers of vacuolated horn cells, with a large amount of keratin in the cytoplasm and cellular organelles. The lambs in the Herbs and $\mathrm{Zn}+$ Herbs groups had ruminal papillae with diverse histological structures, mostly the size of the papillae and type and number of keratinized epithelial cells. Butyrate stimulates the development of ruminal papillae (59), but the in vitro molar proportion of $n$-butyrate was higher only in the $\mathrm{Zn}$ and $\mathrm{Zn}+$ Herbs groups. The amount of ruminal VFA absorption can decrease as ruminal parakeratosis increases (60), and a physical barrier could reduce the transport of VFAs to the deepest layers of the epithelium. The health of the ruminal epithelium probably deteriorated because the infiltration of inflammatory cells in individual papillae in the epithelial layer and the lamina propria was focally mixed in the lambs in the Herbs and $\mathrm{Zn}+$ Herbs groups, respectively. The hematological parameters of the lambs, however, were not affected by the treatments. The application of the Herbs treatment for $70 \mathrm{~d}$ may have been too long.

Nutraceuticals provide health benefits beyond basic nutrition. The vast number of naturally occurring health-enhancing substances are of herbal origin, but many physiologically active components, such as trace elements, also play important roles in the promotion of animal health. Limited information is available on the effects of nutraceuticals such as zinc and/or herbs on blood profiles $(16,61)$. Pharmacological and clinical studies suggest that M. sylvestris, A. absinthium and M. chamomilla are promising herbs for the treatment of gastrointestinal disorders (62). Dietary supplementation with $A$. absinthium can also enhance the rate of growth of lambs, thereby increasing weight gains (63). Different nutrients, however, may generally improve the absorptive capability of the ruminal epithelium, protect the epithelium against damage and alter the expression of genes regulating ruminal epithelial morphology (64-66).

\section{CONCLUSIONS}

The ability of dietary supplementation with organic zinc (70 mg $\mathrm{Zn} / \mathrm{kg}$ diet) and herbs $(100 \mathrm{~g} \mathrm{DM} / \mathrm{d})$ to influence ruminal fermentation and the composition of ruminal microbiota in vitro was not confirmed in vivo. The dietary supplements did not significantly affect the parameters of ruminal fermentation or the protozoal population of the lambs, probably because the lambs adapted to the diets during the 70-d feeding, with lower total bacteria and a shift in the relative abundances of cellulolytic and amylolytic bacteria in the Zn group. Our results, however, also indicated that long-term dietary supplementation with organic zinc combined with a mixture of medicinal herbs could negatively affect the health of the ruminal epithelium. More in vivo experiments are therefore necessary.

\section{DATA AVAILABILITY STATEMENT}

The original contributions presented in the study are included in the article/supplementary material, further inquiries can be directed to the corresponding author/s.

\section{ETHICS STATEMENT}

The animal study was reviewed and approved by the Ethical Committee of the Institute of Animal Physiology of Centre of Biosciences of SAS approved the experimental protocol (resolution number Ro-3355/16-221).

\section{AUTHOR CONTRIBUTIONS}

DP, DM, and KK: resources, formal analysis, and investigation. $\mathrm{PK}, \mathrm{HH}$, and DM: investigation, methodology, and software. SK: investigation and methodology. AL: histological analyses. SS: bioactive compound analysis. AC and MS-S: conceptualization and data curation. KC: project administration, funding acquisition, and supervision. ZV: validation, writing-review, and editing. All authors read and approved the final manuscript.

\section{FUNDING}

This study was supported by funds from the Slovak Research and Development Agency (APVV-17-0297 and APVV-18-0131). Rumen microbial quantification and histological parameters were supported by the framework of the Ministry of Science and Higher Education programme "Regional Initiative Excellence" in years 2019-2022 (Project No. 005/RID/2018/19).

\section{ACKNOWLEDGMENTS}

The authors are grateful to V. Venglovská, R. Geročová, P. Jerga, and G. Benkovský for their laboratory and technical assistance. The English has been revised throughout the whole manuscript by a native English language editor, Dr. William Blackhall. 


\section{REFERENCES}

1. Matthews C, Crispie F, Lewis E, Reid M, O’Toole PW, Cotter PD. The rumen microbiome: a crucial consideration when optimising milk and meat production and nitrogen utilisation efficiency. Gut microbes. (2019) 10:11532. doi: $10.1080 / 19490976.2018 .1505176$

2. Newbold CJ, Ramos-Morales E. Review: Ruminal microbiome and microbial metabolome: effects of diet and ruminant host. Animal. (2020) 1:78-86. doi: $10.1017 /$ S1751731119003252

3. Wencelová M, Váradyová Z, Mihaliková K, Cobanová K, Plachá I, Pristaš $\mathrm{P}$, et al. Rumen fermentation pattern, lipid metabolism and the microbial community of sheep fed a high-concentrate diet supplemented with a mix of medicinal plants. Small Rumin Res. (2015) 125:64-72. doi: 10.1016/j.smallrumres.2015.01.028

4. Váradyová Z, Mravčáková $\mathrm{D}$, Holodová $\mathrm{M}$, Grešáková L, Pisarčíková J, Barszcz $\mathrm{M}$, et al. Modulation of ruminal and intestinal fermentation by medicinal plants and zinc from different sources. J Anim Physiol Anim Nutr. (2018) 102:1131-45. doi: 10.1111/jpn.12940

5. Mravčáková D, Váradyová Z, Kopčáková A, Cobanová K, Grešáková L, Kišidayová $S$, et al. Natural chemotherapeutic alternatives for controlling of haemonchosis in sheep. BMC Vet. Res. (2019) 15:302. doi: 10.1186/s12917-019-2050-2

6. Mravčáková $\mathrm{D}$, Komáromyová $\mathrm{M}$, Babják $\mathrm{M}$, Urda Dolinská $\mathrm{M}$, Königová A, Petrič D, et al. Anthelmintic activity of wormwood (Artemisia absinthium L.) and mallow (Malva sylvestris L.) against Haemonchus contortus in sheep. Animals. (2020) 10:219. doi: 10.3390/ani10020219

7. Ibrahim KS, El-Sayed EM. Potential role of nutrients on immunity. Int Food Res J. (2016) 23:464-74.

8. Hilal EY, Elkhairey MAE, Osman AOA. The role of zinc, manganese and copper in rumen metabolism and immune function: a review article. Open J Anim Sci. (2016) 6:304-24. doi: 10.4236/ojas.2016.64035

9. Spears JW. Trace mineral bioavailability in ruminants. J Nutr. (2003) 133:1506S-9. doi: 10.1093/jn/133.5.1506S

10. Spears JW, Schlegel P, Seal MC, Lloyd KE. Bioavailability of zinc from zinc sulfate and different organic zinc sources and their effects on ruminal volatile fatty acid proportions. Livest Prod Sci. (2004) 90:211-7. doi: 10.1016/j.livprodsci.2004.05.001

11. EFSA. Scientific Opinion on the potential reduction of the currently authorised maximum zinc content in complete feed. EFSA J. (2014) 12:3668. doi: 10.2903/j.efsa.2014.3668

12. López-Alonso M. Trace minerals and livestock: not too much not too little. ISRN Vet Sci. (2012) 2012:704825. doi: 10.5402/2012/704825

13. Graham C, Simmons NL. Functional organization of the bovine rumen epithelium. Am J Physiol Regul Integr Comp Physiol. (2005) 288:R173-81. doi: 10.1152/ajpregu.00425.2004

14. Moens E, Veldhoen M. Epithelial barrier biology: good fences make good neighbours. Immunology. (2012) 135:1-8. doi: 10.1111/j.1365-2567.2011.03506.x

15. Petrič $\mathrm{D}$, Mravčáková $\mathrm{D}$, Kucková $\mathrm{K}$, Cobanová $\mathrm{K}$, Kišidayová $\mathrm{S}$, Cieslak A, et al. Effect of dry medicinal plants (wormwood, chamomile, fumitory and mallow) on in vitro ruminal antioxidant capacity and fermentation patterns of sheep. J Anim Physiol Anim Nutr. (2020) 104:1219-32. doi: 10.1111/jpn. 13349

16. Váradyová Z, Mravčáková D, Babják $M$, Bryszak M, Grešáková L, Cobanová $\mathrm{K}$, et al. Effects of herbal nutraceuticals and/or zinc against Haemonchus contortus in lambs experimentally infected. BMC Vet Res. (2018) 14:78. doi: 10.1186/s12917-018-1405-4

17. European Commission (EC). Council Regulation (EC) 1099/2009 of 24 September 2009 on the protection of animals at the time of killing. Off J Eur Union. (2009) L303:1-30.

18. Yánez-Ruiz DR, Bannink A, Dijkstra J, Kebreab E, Morgavi DP, O’Kiely P, et al. Design, implementation and interpretation of in vitro batch culture experiments to assess enteric methane mitigation in ruminants-a review. Anim Feed Sci Technol. (2016) 216:1-18. doi: 10.1016/j.anifeedsci.2016.03.016

19. McDougall EI. Studies on ruminant saliva. I. The composition and output of sheep's saliva. Biochem J. (1948) 43:99-109.

20. Association of Official Analytical Chemists. Official Methods of Analysis of AOAC International. Washington, DC (2000).
21. Van Soest PJ, Robertson JB, Lewis BA. Methods for dietary fiber neutral detergent fiber, and non-starch polysaccharides in relation to animal nutrition. J Dairy Sci. (1991) 74:3583-97. doi: 10.3168/jds.S0022-0302(91)78551-2

22. Wencelová $M$, Váradyová $Z$, Pristaš $P$, Cobanová $K$, Plachá $I$, Kišidayová S. Effects of diet supplementation with herbal blend and sunflower seeds on fermentation parameters, microbial population, and fatty acid profile in rumen of sheep. Czech J Anim Sci. (2016) 61:551-9. doi: 10.17221/17/2016-CJAS

23. Moss AR, Jouany JP, Newbold J. Methane production by ruminants: its contribution to global warming. Ann Zootech. (2000) 49:231-53. doi: 10.1051/animres:2000119

24. Broderick GA, Kang JH. Automated simultaneous determination of ammonia and total amino acids in ruminal fluid and in vitro media. J Dairy Sci. (1980) 63:64-75. doi: 10.3168/jds.S0022-0302(80)82888-8

25. Williams AG, Coleman GS. The Rumen Protozoa. New York, NY: Springer Verlag (1992).

26. Henderson G, Cox F, Kittelmann S, Miri VH, Zethof M, Noel SJ, et al. Effect of DNA Extraction methods and sampling techniques on the apparent structure of cow and sheep rumen microbial communities. PLoS ONE. (2013) 8:e74787. doi: 10.1371/journal.pone.0074787

27. Stevenson DM, Weimer PJ. Dominance of Prevotella and low abundance of classical ruminal bacterial species in the bovine rumen revealed by relative quantification real-time PCR. Appl Microbiol Biotechnol. (2007) 75:165-74. doi: 10.1007/s00253-006-0802-y

28. Erlund I. Review of the flavonoids quercetin, hesperetin, and naringenin. Dietary sources, bioactivities, bioavailability, and epidemiology. Nutr Res. (2004) 24:851-74. doi: 10.1016/j.nutres.2004.07.005

29. Al-Snafi AE. Constituents and pharmacology of Fumaria officinalis - A review. IOSR J Pharm. (2020) 10:17-25.

30. Sullivan ML, Zeller WE. Efficacy of various naturally occurring caffeic acid derivatives in preventing post-harvest protein losses in forages. J Sci Food Agric. (2013) 93:219-26. doi: 10.1002/jsfa.5781

31. Salehi B, Venditti A, Sharifi-Rad M, Kregiel D, Sharifi-Rad J, Durazzo A, et al. The therapeutic potential of apigenin. Int J Mol Sci. (2019) 20:1305. doi: 10.3390/ijms20061305

32. Kumar S, Pandey AK. Chemistry and biological activities of flavonoids: an overview. Sci World J. (2013) 2013:162750. doi: 10.1155/2013/162750

33. Sato Y, Itagaki S, Kurokawa T, Ogura J, Kobayashi M, Hirano T, et al. In vitro and in vivo antioxidant properties of chlorogenic acid and caffeic acid. Int $J$ Pharm. (2011) 403:136-8. doi: 10.1016/j.ijpharm.2010.09.035

34. Tajik N, Tajik M, Mack I, Enck P. The potential effects of chlorogenic acid, the main phenolic components in coffee, on health: a comprehensive review of the literature. Eur J Nutr. (2017) 56:2215-44. doi: 10.1007/s00394-017-1379-1

35. Braham H, Mighri Z, Jannet HB, Matthew S, Abreu PM. Antioxidant phenolic glycosides from Moricandia arvensis. J Nat Prod. (2005) 68:517-22. doi: $10.1021 / \mathrm{np} 049581 \mathrm{~m}$

36. Santos MD, Chen G, Almeida MC, Soares DM, de Souza GE, Lopes NP et al. Effects of caffeoylquinic acid derivatives and C-flavonoid from Lychnophora ericoides on in vitro inflammatory mediator production. Nat Prod Commun. (2010) 5:733-40.

37. Berger LM, Blank R, Zorn F, Wein S, Metges CC, Wolffram S. Ruminal degradation of quercetin and its influence on fermentation in ruminants. $J$ Dairy Sci. (2015) 98:5688-98. doi: 10.3168/jds.2015-9633

38. Broudiscou L-P, Lassalas B. Effects of Lavandula officinalis and Equisetum arvense dry extracts and isoquercitrin on the fermentation of diets varying in forage contents by rumen microorganisms in batch culture. Reprod Nutr Dev. (2000) 40:431-40. doi: 10.1051/rnd:2000110

39. Bodas R, López S, Fernández M, García-González R, Rodríguez AB, Wallace $\mathrm{RJ}$, et al. In vitro screening of the potential of numerous plant species as antimethanogenic feed additives for ruminants. Anim Feed Sci Technol. (2008) 145:245-58. doi: 10.1016/j.anifeedsci.2007.04.015

40. Oskoueian E, Norhani A, Oskoueian A. Effects of flavonoids on rumen fermentation activity, methane production, and microbial population. Biomed Res Int. (2013) 2013:8. doi: 10.1155/2013/349129

41. Cieslak A, Zmora P, Pers-Kamczyc E, Szumacher-Strabel M. Effects of tannins source (Vaccinium vitis idaea L.) on rumen microbial fermentation in vivo. Anim Feed Sci Technol. (2012) 176:102-6. doi: 10.1016/j.anifeedsci.2012.07.012 
42. Kišidayová $S$, Pristaš $\mathrm{P}$, Zimovčáková $\mathrm{M}$, Blanár Wencelová $\mathrm{M}$, Homolová $\mathrm{L}$, Mihaliková K, et al. The effects of high dose of two manganese supplements (organic and inorganic) on the rumen microbial ecosystem. PLoS ONE. (2018) 13:e0191158. doi: 10.1371/journal.pone.0191158

43. Patra AK, Saxena J. A new perspective on the use of plant secondary metabolites to inhibit methanogenesis in the rumen. Phytochemistry. (2010) 71:1198-222. doi: 10.1016/j.phytochem.2010.05.010

44. Patra $\mathrm{AK}, \mathrm{Yu} \mathrm{Z}$. Effects of adaptation of in vitro rumen culture to garlic oil, nitrate, and saponin and their combinations on methanogenesis, fermentation, and abundances and diversity of microbial populations. Front Microbiol. (2015) 6:1434. doi: 10.3389/fmicb.2015.01434

45. Ishaq SL, Page CM, Yeoman CJ, Murphy TW, Van Emon ML, Stewart WC. Zinc AA supplementation alters yearling ram rumen bacterial communities but zinc sulfate supplementation does not. J Anim Sci. (2019) 97:687-97. doi: 10.1093/jas/sky456

46. Patra A, Park T, Kim M, Yu Z. Rumen methanogens and mitigation of methane emission by anti-methanogenic compounds and substances. J Anim Sci Biotechnol. (2017) 8:13. doi: 10.1186/s40104-017-0145-9

47. VanValin KR, Genther-Schroeder ON, Carmichael RN, Blank CP, Deters EL, Hartman SJ, et al. Influence of dietary zinc concentration and supplemental zinc source on nutrient digestibility, zinc absorption, and retention in sheep. $J$ Anim Sci. (2018) 96:5336-44. doi: 10.1093/jas/sky384

48. Wang RL, Liang JG, Lu L, Zhang LY, Li SF, Luo XG. Effect of zinc source on performance, zinc status, immune response, and rumen fermentation of lactating cows. Biol Trace Elem Res. (2013) 152:16-24. doi: 10.1007/s12011-012-9585-4

49. Chen M, Xi Y, Zhang L, Zeng H, Li Y, Han Z. Effects of zinc-bearing palygorskite on rumen fermentation in vitro. Asian-Aust J Anim Sci. (2019) 32:63-71. doi: 10.5713/ajas.17.0920

50. Froetschel MA, Martin AC, Amos HE, Evans JJ. Effects of zinc sulfate concentration and feeding frequency on ruminal protozoal numbers, fermentation patterns and amino acid passage in steers. J Anim Sci. (1990) 68:2874-84. doi: 10.2527/1990.6892874x

51. Maret W, Sandstead HH. Zinc requirements and the risks and benefits of zinc supplementation. J Trace Elem Med Biol. (2006) 20:3-18. doi: 10.1016/j.jtemb.2006.01.006

52. Maret W. Zinc biochemistry: from a single zinc enzyme to a key element of life. Adv Nutr. (2013) 4:82-91. doi: 10.3945/an.112.003038

53. Newbold CJ, de la Fuente G, Belanche A, Ramos-Morales E, McEwan NR. The role of ciliate protozoa in the rumen. Front Microbiol. (2015) 6:1313. doi: $10.3389 /$ fmicb. 2015.01313

54. Hernandez-Sanabria E, Goonewardene LA, Wang Z, Durunna ON, Moore SS, Guan LL. Impact of feed efficiency and diet on adaptive variations in the bacterial community in the rumen fluid of cattle. Appl Environ Microbiol. (2012) 78:1203-14. doi: 10.1128/AEM.05114-11

55. De Nardi R, Marchesini G, Li S, Khafipour E, Plaizier KJ, Gianesella M, et al. Metagenomic analysis of rumen microbial population in dairy heifers fed a high grain diet supplemented with dicarboxylic acids or polyphenols. BMC Vet Res. (2016) 12:29. doi: 10.1186/s12917-016-0653-4

56. Bannink A, France J, Lopez S, Gerrits WJ, Kebreab E, Tamminga S, et al. Modeling the implications of feeding strategy on rumen fermentation and functioning of the rumen wall. Anim Feed Sci Technol. (2008) 143:3-26. doi: 10.1016/j.anifeedsci.2007.05.002
57. Melo LQ, Costa SF, Lopes F, Guerreiro MC, Armentano LE, Pereira MN. Rumen morphometrics and the effect of digesta $\mathrm{pH}$ and volume on volatile fatty acid absorption. J Anim Sci. (2013) 91:1775-83. doi: 10.2527/jas.2011-4999

58. Dobson MJ, Brown WCB, Dobson A, Phillipson AT. A histological study of the organization of the rumen epithelium of sheep. Quart J Exptl Physiol. (1956) 41:247-53. doi: 10.1113/expphysiol.1956.sp001186

59. Mentschel J, Leiser R, Mülling C, Pfarrer C, Claus R. Butyric acid stimulates rumen mucosa development in the calf mainly by a reduction of apoptosis. Arch Tierernahr. (2001) 55:85-102. doi: 10.1080/17450390109386185

60. Hinders RG, Owen FG. Relation of ruminal parakeratosis development to volatile fatty acid absorption. J Dairy Sci. (1965) 48:1069-74. doi: 10.3168/jds.S0022-0302(65)88393-X

61. Mandal GP, Dass RS, Varshney VP, Mondal AB. Effect of zinc supplementation from inorganic and organic sources on growth and blood biochemical profile in crossbred calves. I Anim Feed Sci. (2008) 17:147-56. doi: 10.22358/jafs/66478/2008

62. Mayer M, Vogl CR, Amorena M, Hamburger M, Walkenhorst $M$. Treatment of organic livestock with medicinal plants: a systematic review of European ethnoveterinary research. Forsch Komplementmed. (2014) 21:37586. doi: 10.1159/000370216

63. Beigh YA, Mir DM, Ganai AM, Ahmad HA, Muzamil S. Body biometrics correlation studies on sheep fed wormwood (Artemisia absinthium L.) herb supplemented complete diets. Indian J Vet Res. (2019) 28:8-13. doi: 10.5958/0974-0171.2019.00002.5

64. Wang B, Wang D, Wu X, Cai J, Liu M, Huang X, et al. Effects of dietary physical or nutritional factors on morphology of rumen papillae and transcriptome changes in lactating dairy cows based on three different forage-based diets. BMC Genomics. (2017) 18:353. doi: 10.1186/s12864-0173726-2

65. Garcia Diaz T, Ferriani Branco A, Jacovaci FA, Cabreira Jobim C, Bolson DC, Pratti Daniel JL. Inclusion of live yeast and mannanoligosaccharides in high grain-based diets for sheep: Ruminal parameters, inflammatory response and rumen morphology. PLoS ONE. (2018) 13:e0193313. doi: 10.1371/journal.pone.01 93313

66. Jing XP, Peng QH, Hu R, Zou HW, Wang HZ, Yu XQ, et al. Dietary supplements during the cold season increase rumen microbial abundance and improve rumen epithelium development in Tibetan sheep. J Anim Sci. (2018) 96:293-305. doi: 10.1093/jas/skx032

Conflict of Interest: The authors declare that the research was conducted in the absence of any commercial or financial relationships that could be construed as a potential conflict of interest.

Copyright (C) 2021 Petrič, Mravčáková, Kucková, Kišidayová, Cieslak, SzumacherStrabel, Huang, Kolodziejski, Lukomska, Slusarczyk, Čobanová and Váradyová. This is an open-access article distributed under the terms of the Creative Commons Attribution License (CC BY). The use, distribution or reproduction in other forums is permitted, provided the original author(s) and the copyright owner(s) are credited and that the original publication in this journal is cited, in accordance with accepted academic practice. No use, distribution or reproduction is permitted which does not comply with these terms. 